\title{
POLISH DEFENSE STANDARDS WITHIN THE EUROPEAN RANGE
}

\author{
Henryk POPIEL \\ Military University of Technology \\ Bogusław Rogowski \\ Military University of Technology \\ Krzysztof WALCZAK \\ Military Center for Standardization
}

\begin{abstract}
The article is an account of activities conducted in the field of standardization related to State defence and security for the development of military standards in the area of water supply for forces in field conditions. This adheres to the level of European defence standardization procesess. Thus, a type of summary has been presented of this not so popular case, when - for the very first time in the history of Polish military standardization - national defence standards have become the standards within the European range. What has been pointed out in this aspect is the importance and the need to promote - in a similar way - the achievements of military standardization in other areas of social and economic life, especially in the field of State defence and security, as well as anywhere where Poland has a potential and considerable achievements on a global scale. Such actions - except for a considerable contribution to improving a positive image of Poland in international relations - may be one of the ways to gain a more effective access to information and markets, education and development.
\end{abstract}

Keywords: engineering technology, European defence procurement market, standard, standardization, water supply for forces

\section{INTRODUCTION}

A consistent and methodological foreign cooperation, in a bilateral and multilateral scope - sooner or later - should result in measurable benefits for the parties involved in the cooperation. This well known and commonly applied rule, enriched above all by the attractiveness of the initiating party's cooperation offer, can also be applied in the field of standardization. There are many fields and possibilities of cooperation, as well as achievements - however, very often such activities lack effective promotion, and especially broadened information about the projects carried out. Promoting such activities would surely improve the image of Polish achievements on the national level, as well as on the international one, and it would also increase the standardization awareness among people and bodies interested in this field.

This article contains a brief characterization of one of the most important projects from the area of defence, concerning the development of Defence Standards, which 
have been considered in the European standardization environment. The project has been carried out as part of the EDSIS, i.e. the European Defence Standardization Information System) - which is an important fact in the history of the Polish military standardization's achievements in the field of water extraction, treatment and distribution in extraordinary situations, or in the so-called field conditions.

\section{The water supply for forces in the field conditions - Polish speciality. The beginning of cooperation}

In most cases the beginnings of cooperation are uneasy, especially in new areas and very often in those, which - except for the well-prepared content offer - require the winning of trust among the parties. It was similar in the case described in this article. A lot of time had to pass in order for Poland's initiative to become fully mature and gain approval on the European level. The final success was a result of a number of factors making for the practical use of the Polish experiences and scientific achievements, including the need to organize a system of water supply for forces, including the Polish Military Contingent operating as part of the UN peacekeeping mission in the Republic of Chad.

However, there are not many people from the so-called 'branch' who remember that the beginning of this - important in the scale of the Ministry of Defence - standardization undertaking date back to 2001. It began with the exchange of experiences between the Military Centre for Standardization, Quality and Codification (WCNJiK) and the Federal Office of Defence Technology and Procurement (Bundesamt für Wehrtechnik und Beschaffung - BWB) in Koblenz in the field of materiel standardization. As a result of the mutual visits (once a year) the process of making closer contacts on the level of military research and development bodies of Germany and Poland was initiated. It has to be mentioned at this point that e.g. as a result of a German delegation's visit to Poland in 2004, with the participation of representatives of research and development institutes, the achievements of among others - the Military Institute of Armament Technology in Zielonka and the Air Force Institute of Technology in Warsaw were presented. It allowed to initiate direct contacts between these research and development bodies, which resulted in the invitation of their representatives to visit their counterparts in Germany in 2005. The visit was carried out and its result was the inclusion of other MOD research and development bodies from the areas of armament, aviation, engineer and sapper technology, and camouflage, in the cooperation.

Moreover, as a result of a big interest in a direct cooperation of institute representatives, broadened with the exchange of experiences at the European Defence Agency and NATO forums, the 4-Nations meetings were initiated (Germany, France, Great Britain and Poland) for the exchange of information in the area of materiel 
standardization and the development of joint standardization projects. The consultation took place in Poland. Its coordinator was the WCNJiK. National experiences were exchanged and the result was the agreement of proposals for joint standardization projects that would also be supported at the NATO forum. The meeting also resulted in the inclusion of further MOD research and development bodies in the cooperation, whose measurable outcome was the delegation of a dozen or so Polish representatives to working groups of the European Committee for Standardization in the area of defence standardization, as well as forming a joint initiative in an attempt to develop military standards from the field of water extraction, treatment and supply for forces in field conditions. With regard to this issue, in 2007 the Military Centre for Standardization, Quality and Codification, together with military research and development bodies, initiated the need to become involved in such works in the area of defence standardization, searching for volunteers to participate in such an initiative. For this purpose, a series of information and training meetings have been organized for future MOD project executors, and working contacts have been initiated with foreign partners more experienced in this issue.

As a result of the undertaken actions, the Military Institute of Engineer Technology in Wroclaw has been identified as the main executor of all works, as the most renown research and development body in this area. The agreement of the Military Institute of Engineer Technology leadership was not meaningless for the cooperation in the project and for the acceptance of the role of the executor and organizer of preparatory works with the aim to define the subject of standards, as the crucial part of the project.

With great regret the information from the leadership of the MOD Military Education Department's leadership of that time had to be accepted that the Department had no possibility to support the project, especially in the financial scope. Under such circumstances the coordination of the project on the MOD level, the formal and content services for the subjects through placing them in the appropriate planning documents, both in the MOD and within the EDSIS system, as well as the assistance in developing the necessary documentation for managing the project, and partial financing of the works were taken over by the WCNJiK.

\section{Initiation of standardization Works}

The condition for the initiation of standardization works, in concordance with legal requirements and standardization principles, was the qualification of the standardization subject for realization as part of the MOD programme and plan of standardization works. An additional condition was placing the subjects in the aforementioned EDSIS system, but fulfilling it was not that difficult as the initiative gained lots of support from all the involved parties. Moreover, the need to initiate 
the works was accepted by other foreign partners, and the proposed subjects were considered very interesting, also from the point of view of operational backup for combat operations, peacekeeping missions and multinational military contingents operating under the auspices of the UN, EU and NATO' ${ }^{1}$.

The Military Institute of Engineer Technology (WITI) has carried out a number of preparatory and subject undertakings, making it possible to officially present and propose five standardization subjects from the area of water supply for forces to the EDSIS system during the quadrilateral meeting of representatives from the ministries of defence of France, Germany, Great Britain and Poland in Berlin in May 2008.

The scope of the project proposed for the EDSIS by the MOD standardization service representatives included the following subjects of planned works, shown in Fig.1, in Polish and English [2].

a) Terminology and classification of field devices for treatment, distribution and storage of water,

b) Requirements and test methods of water treatment field devices,

c) Requirements and test methods of operating materials for water treatment field devices,

d) Minimum requirements of water for treatment purposes,

e) Sampling methods for water testing.

The scope of regulation for the above-mentioned subjects included respectively: ad. a)

- terminology related to field devices for treatment, distribution and storage of water;

- classification of technical means for transport and storage of drinking water and water extraction in field conditions;

- classification and markings of water installation.

ad. b)

- general requirements for water treatment devices meant for obtaining water for the necessities of life in field supply for forces from polluted sources and those contaminated with poisonous and radioactive substances, as well as biological agents;

- test methods of field devices for water treatment and their components.

\footnotetext{
${ }^{1}$ More information on the subject can be found in a report on the aforementioned meeting that has been sent to the MOD Military Education Department (DNiSW), outgoing letter no. 1498 dated 30.06.2008, and in the report from the EDA Materiel Standardization Harmonisation Team (MSHT) meeting in Brussels on 15-16.07.2008 (outgoing letter no. 1724 dated 29.07.2008).
} 


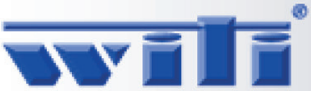

\section{AREAS OF POSSIBLE COOPERATION}

- term inology and classification of field devices for treatment, distribution and storage of water;

- requirem ents and test $m$ ethods of water treatment field devices;

- requirem ents and test $m$ ethods of operating materials for water treatment field devices;

- minim um requirements of water for treatment purposes;

- sampling methods for water testing ;
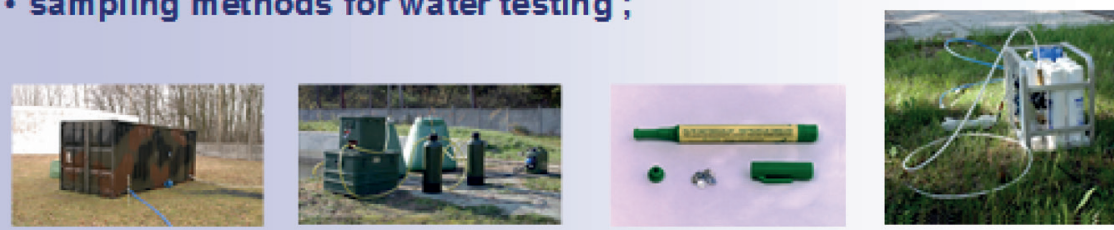

\section{1}

Fig. 1. Areas of cooperation proposed by the WITI Wroclaw as part of the EDSIS system. Source WITI materials for presentation by the WCNJiK delegation during the quadrilateral meeting of representatives from the ministries of defence of France, Germany, Great Britain and Poland in Berlin in May 2008

ad. c)

- requirements and test methods for periodically exchanged operating materials used in field (military) stations and sets for water treatment and individual filters, such as filtration-sorption materials, ion exchange resins, disinfecting agents, coagulants and positive ion regeneration means;

- rules of storage and rotation of operating materials, including a list of materials subject to rotation and their durability times;

- guidelines for the disposal of outdated reagents and materials, as well as safety principles for those activities;

- ways of packing and marking operating materials.

ad. d)

- maximum level of pollution and contamination of water for treatment with poisonous and radioactive substances, as well as biological agents in field devices for water treatment.

ad. e) 
- sampling methods of natural waters (surface and underground), meant for treatment in field water treatment devices, in order to identify their physical, chemical and microbiological parameters in field water quality control laboratories;

- principles of sampling water treated with the use of military water treatment stations and sets for examination of physical, chemical and microbiological parameters in field conditions;

- rules for the organization and conduct of water sampling in order to ensure their representativeness.

At the same time, in concordance with the MOD rules of standardization works programming and planning, on the basis of point 6.1.33 of 'Standardization works' principles in the MOD', which form the attachment to decision no. 191/MON of the Minister of National Defence dated 14 July 2004, the below subjects of standardization works for the development of Defence Standards were included in the 'MOD Programme of standardization works for the years 2009-2011'. After the final agreement they read as follows:

- Terminology and classification of field devices for treatment, distribution and storage of water,

- Requirements and test methods of water treatment field devices,

- Requirements and test methods of operating materials for water treatment field devices,

- Minimum requirements of water for treatment purposes,

- Water sampling methods for tests in field conditions.

At the same time financing the subjects was planned as part of the expanses for the MOD standardization works with only a slight increase in the costs of their development in comparison with national products, including e.g. their parallel translation to English. This activity was the final crowning achievement of the works initiating the project more than five years earlier. After meeting a series of formal requirements, the first four out of five standard subjects were placed in the EDSIS system, destined for realization [3].

As far as the draft standard proposal entitles Water sampling methods for tests in field conditions its realization is scheduled to begin in 2013, after placing the subject in planning documents and the initiation of works by the WITI.

\section{EDSIS system complete with Polish Defence Standards}

At this point it seems adequate to devote some attention to the European Defence Standardization Information System, abbreviated to EDSIS. It is the basic, and even key, element of integrating the European defence procurement market. The purpose of the system is to achieve full transparency in the field of development by the members of the European Defence Agency (EDA) of products in the form of 
Defence Standards. It is expected that filling the common database with information on the needs in the area of defence standardization will make it possible to effectively exchange information and encourage the nations to participate more actively in the works of this field. At the same time such activities may result in measurable economic effects in the form of cost rationalization, resulting from the limiting of repetition in standardization works in the same areas by given nations in favor of the realization of common projects. On the level of EDA member nations the coordinators of works are the ministries of defence, whereas the coordinating institutions are the bodies responsible for defence standardization - in the case of the Polish Ministry of Defence - the WCNJiK [1]. Moreover, it is assumed that the Defence Standards developed as part of the EDSIS system - with a broad cooperation of the ministries of defence of given nations - will be 'automatically' qualified as standards of the so-called best practice and will be included in the European Handbook for Defense Procurement (EHDP) sponsored by the European Commission and coordinated by the EDA.

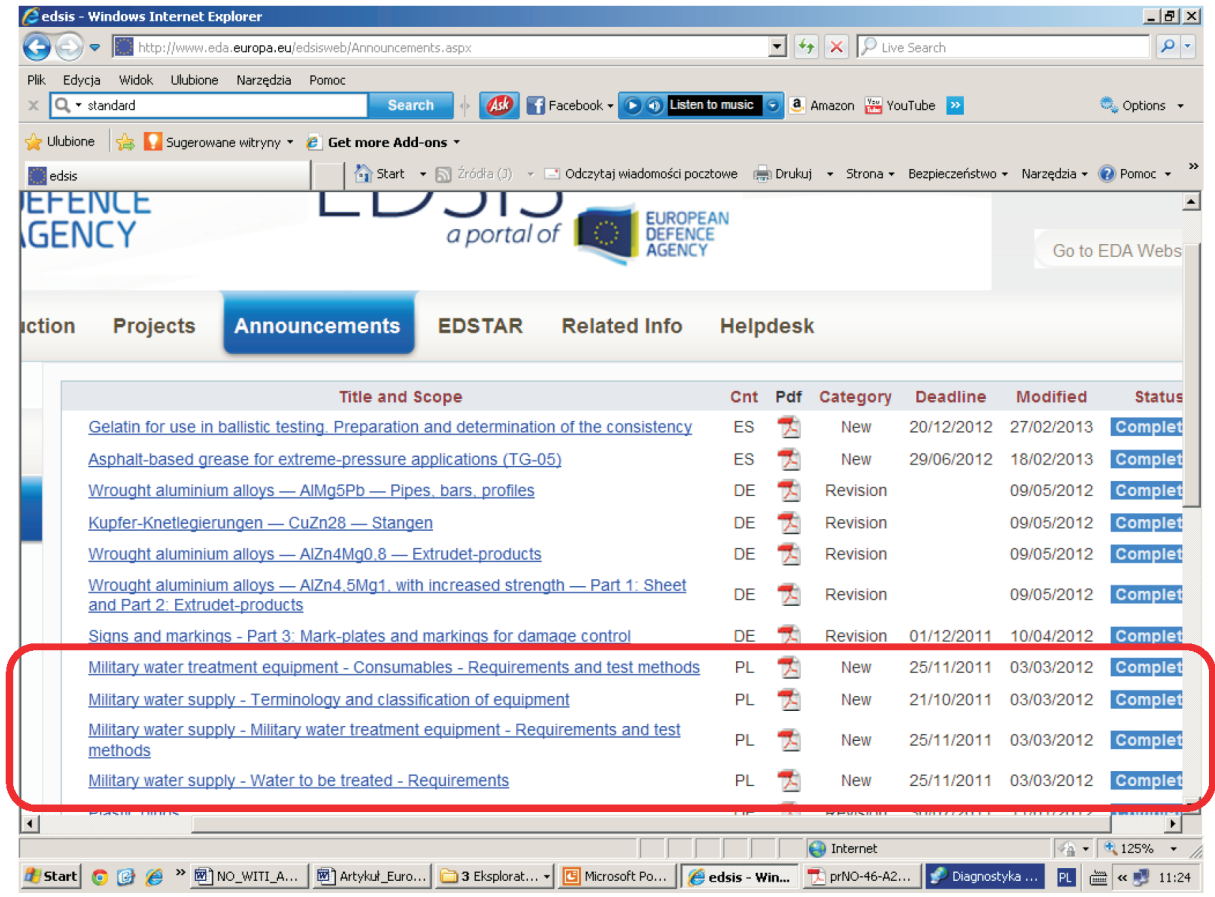

Fig. 2. A list of products in the EDSIS system, with the Polish Defence Standards marked

The next step, and such is the idea of the system's creators and organizers, would be to transpose the requirements included in the Defence Standards to European Standards. Access to the EDSIS system and its contents (including Polish Defence 
Standards) is possible through the www.eda europa.eu/edsisweb website, which has been shown in Fig. 2. As it can be seen from the data on the EDSIS website, works have been completed on four out of five Polish Standards and the full text versions of the products are available in English (Fig. 3).

It is an important, characteristic, and also historical event in the area of Polish military standardization, building our authority in the international environment. A number of factors have contributed to this measurable success, the most important one being - in the authors' opinion - an appropriate, pro-innovative approach and the involvement of the Military Institute of Engineer Technology, as well as the bold presentation of its longstanding achievements in the area, in which the Institute is an equal partner for other foreign bodies of this type, and even a world-class leader. An excellent, highly-qualified scientific staff with a broad subject knowledge, combined with experience and achievements supported by practical solutions, may be a model to be followed by other military scientific bodies - schools and institutes having equally excellent and unique solutions on a European and international scale.

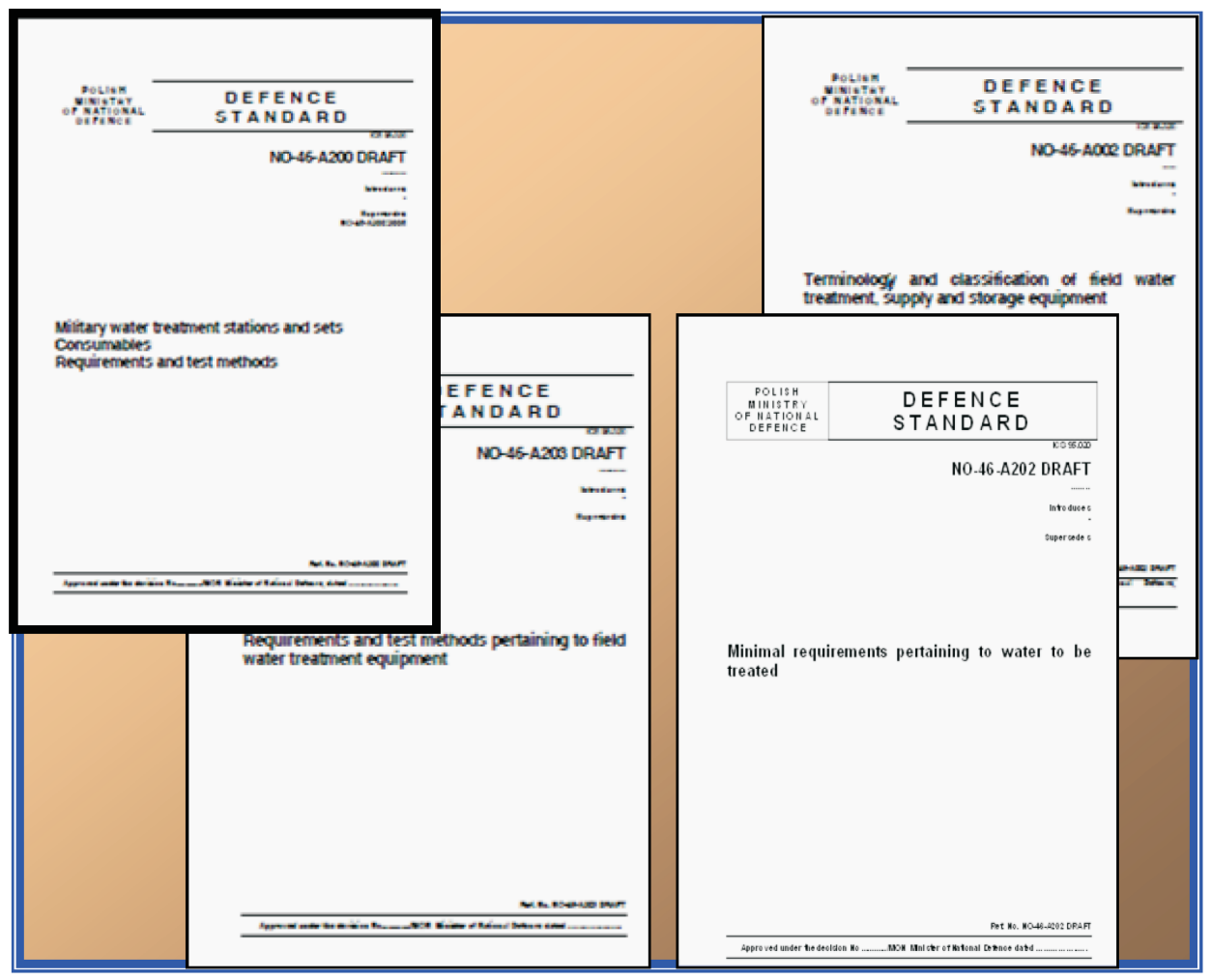

Fig. 3. Polish Defence Standards in the EDSIS system 


\section{Conclusions}

As seen on the basis of the aforementioned example, there are real possibilities to transform the Polish technical thought and scientific achievements into a practical application of experiences, also on an international scale. It is one of the best ways to promote national experiences and solutions, helping to build and multiply a positive image of Poland in the international environment. The achievements presented on the example of one of Polish military institutes are surely not the only ones in the Armed Forces, but their importance is such that they concern an activity of little popularity, which is standardization's involvement on a European level.

Thanks to the involvement and openness of the system's coordinator - the Minister of Defence standardization service whose direct coordinator is the WCNJiK - and especially an appropriate approach and the conviction of the leadership and the experts from the Military Institute of Engineer Technology this briefly characterized project has been fully carried out. After the final placement of the standards in the documentation collection from the aforementioned area of the so-called best practice, perhaps in the future the result will be that new contracts will be awarded to the Institute in this field, e.g. as part of the European, common market of defence orders.

Even if it does not happen, a measurable benefit of this undertaking is raising the renown of the Military Institute of Engineer Technology and other military research and development bodies, as well as promoting and popularizing the Polish achievements and experiences. It should, at least at the very minimum, make up for the intellectual effort and organizational difficulties, and above all the financial expanses made from the own resources of the WITI, one of the oldest research and development bodies of the Institute.

\section{REFERENCES}

1. The Council of the Ministers Decree dated 23 December 2002 on standardization related to State defence and security (Journal of Laws no. 239, item 2038).

2. http://www.eda europa.eu/edsisweb - 22.09.2014.

3. http://www.wcnjk.wp.mil.pl/pl/13.html - section 'Standardization' - 22.09.2014.

\section{POLSKIE STANDARDY OBRONNOŚCI W RAMACH EUROPEJSKICH}

Streszczenie: $\mathrm{W}$ artykule przedstawione są doświadczenia związane z procesem standaryzacji związanym z obronnością państwa i rozwiązaniami dotyczącymi dostępu do wody dla sił działających $\mathrm{w}$ warunkach polowych. Temat jest powiązany $\mathrm{z}$ europejskim procesem standaryzacji $\mathrm{w}$ tym zakresie. Jak przekrojowo pokazali autorzy, mamy do czynienia z sytuacją, gdzie po raz pierwszy w historii - dla polskiej standaryzacji wojskowej - standardy obronne zostały zaadaptowane w sferę obronności europejskiej. Autorzy zwracają uwagę, że konieczne jest promowanie tego typu działań również z innych przestrzeni naszej standaryzacji wojskowej. Zwłaszcza w ramach obronności państwa i bezpieczeństwa, ale również tam, gdzie Polska ma zarówno możliwości potencjalne, jak i sukcesy globalne. Promowanie takich działań, a nie wyłącznie kierowanie uwagi na poprawę wizerunku samego w sobie, będzie miało 
wyraźny wpływ na pozycję Polski w stosunkach międzynarodowych. Może też być jednym ze sposobów uzyskania dostępu do informacji i rynków, zasobów edukacyjnych i rozwoju.

Słowa kluczowe: inżynieria technologii, rynek europejskiej obronności, standard, standaryzacja, zasoby wodne dla obronności. 